\title{
Synthesis, Spectroscopic Characterization, and Biological Activities of Metal Complexes of 4-((4-Chlorophenyl) diazenyl)-2-((p-tolylimino)methyl)phenol
}

\author{
C. Anitha, ${ }^{1}$ C. D. Sheela, ${ }^{2}$ P. Tharmaraj, ${ }^{3}$ and V. V. Hema ${ }^{2}$ \\ ${ }^{1}$ Department of Chemistry, Fatima Michael College of Engineering \& Technology, Madurai 625 020, India \\ ${ }^{2}$ Department of Chemistry, The American College, Tamilnadu, Madurai 625 002, India \\ ${ }^{3}$ Department of Chemistry, Thiagarajar College, Tamilnadu, Madurai 625 009, India \\ Correspondence should be addressed to P. Tharmaraj; sheelatharmaraj@gmail.com
}

Received 10 June 2012; Accepted 20 August 2012

Academic Editor: Ai-Min Ren

Copyright (C) 2013 C. Anitha et al. This is an open access article distributed under the Creative Commons Attribution License, which permits unrestricted use, distribution, and reproduction in any medium, provided the original work is properly cited.

\begin{abstract}
Azo Schiff base complexes of $\mathrm{VO}(\mathrm{II}), \mathrm{Mn}(\mathrm{II}), \mathrm{Co}(\mathrm{II}), \mathrm{Ni}(\mathrm{II}), \mathrm{Cu}(\mathrm{II})$, and $\mathrm{Zn}(\mathrm{II})$ have been synthesized from 4-((4chlorophenyl)diazenyl)-2-((p-tolylimino)methyl)phenol (CDTMP). The nature of bonding and the structural features of the complexes have been deduced from elemental analysis, molar conductance, magnetic susceptibility measurements, IR, UV-Vis, ${ }^{1}$ H-NMR, EPR, mass, SEM, and fluorescence spectral studies. Spectroscopic and other analytical studies reveal square-planar geometry for copper, square-pyramidal geometry for oxovanadium, and octahedral geometry for other complexes. The EPR spectra of copper(II) complex in DMSO at $300 \mathrm{~K}$ and $77 \mathrm{~K}$ were recorded, and its salient features are reported. Antimicrobial studies against several microorganisms indicate that the complexes are more potent bactericides and fungicides than the ligand. The electrochemical behavior of the copper(II) complex was studied by cyclic voltammetry. All the synthesized compounds can serve as potential photoactive materials as indicated from their characteristic fluorescence properties. The second harmonic conversion efficiency of the synthesized azo Schiff base was found to be higher than that of urea and KDP (potassium dihydrogen phosphate). SEM image of copper(II) complex implies the crystalline state and surface morphology of the complex.
\end{abstract}

\section{Introduction}

Azo compounds are the largest class of industrially synthesized organic dyes due to their versatile application in various fields, such as dyeing textile fiber, biomedical studies, and advanced application in organic synthesis and high technology areas such as laser, liquid crystalline displays, and electrooptical devices [1]. The oxidation-reduction behaviors of these compounds play an important role in its biological activity $[2,3]$. The architectural beauty of these coordination complexes arises due to the interesting ligand systems containing different donor sites [4]. Azomethine derivatives are widely applied in biological systems and dyes [5]. In recent years, there is considerable interest in the synthesis and modeling of new organic materials with optical nonlinearities because of their potential use in development of photonic devices [6].
Azo ligands containing salicylaldimine-based side chains can be used in the production of chemical sensors because they show a significant change of color of the solution and maxima of the absorption band when they interact with transition metal atoms. Transition metal-complexed azomethine compounds have been studied in great detail in the literature for understanding their optical and electronic properties, structure-redox relationships, and mesogenic characteristics $[7,8]$. It could be expected that design and synthesis of transition metal complexes derived from azo Schiff base ligands might be a possible way to obtain the applicable nonlinear optical materials [9]. In particular $p$-nitroaniline, $\mathrm{m}$-nitroaniline, $p$-nitro-N,N-dimethylaniline, and other similar choromophores were found to exhibit rather large NLO properties [10]. Although many Schiff bases derived from aromatic aldehydes and amines and their corresponding metal complexes have been extensively studied, relatively few 
azo-linked Schiff bases and their metal complexes have been reported $[11,12]$.

1.1. Scope. Design and synthesis of transition metal complexes derived from azo Schiff base ligands might be a possible way to obtain the applicable nonlinear optical materials, endowed with antiviral activity, optical activity, electronic activity, and so forth. The electron-pull and electron-push substituents on the benzene rings have much influence on the electronic structure of azo compounds to possess a larger nonlinear optical susceptibility. Because of the importance of azo-containing compounds and our interest in syntheses of nonlinear optical materials, we report herein the syntheses, spectroscopic studies and biological activities of azo Schiff base derivative 4-((4-chlorophenyl)diazenyl)-2((p-tolylimino)methyl)phenol (CDTMP) which have donor and acceptor property due to electron-pull and electron-push substituents ( $\mathrm{Cl}$ and $\mathrm{CH}_{3}$ groups) and their $\mathrm{VO}$ (II), $\mathrm{Mn}$ (II), $\mathrm{Co}(\mathrm{II}), \mathrm{Ni}(\mathrm{II}), \mathrm{Cu}(\mathrm{II})$, and $\mathrm{Zn}(\mathrm{II})$ complexes. We are also interested to examine the antimicrobial, fluorescence, NLO, and redox properties of these azo Schiff base compounds.

\section{Experimental}

The chemicals and solvents were purified by standard methods. Elemental analyses were carried out using a PerkinElmer 2400 II elemental analyzer. Molar conductance of the complexes was measured in DMSO at room temperature using a Systronic Conductivity Bridge 304. Magnetic susceptibility of the complexes was performed on a Sherwood MSB mark 1 Gouy balance. Infrared spectral studies were carried out on a Shimadzu FT IR 8000 spectrophotometer using $\mathrm{KBr}$ discs. UV-Vis spectra were obtained using a Thermo Spectronic 6 Hexios $\alpha$, and fluorescence spectra were determined with an Elico SL174 Spectrofluorometer. NMR spectra were recorded on Bruker DRX-300, $300 \mathrm{MHz}$ NMR Spectrometer using TMS as reference. EPR spectra of the $\mathrm{Cu}(\mathrm{II})$ and $\mathrm{VO}$ (II) complexes were recorded in Varian E112 machine at 300 and $77 \mathrm{~K}$ using TCNE (Tetracyanoethylene) as the g-marker. Cyclic voltammetric measurements for $\mathrm{Cu}(\mathrm{II})$ and $\mathrm{VO}(\mathrm{II})$ complexes in DMSO were carried out on Electrochemical Analyzer $\mathrm{CH}$ Instruments (USA) using a three-electrode cell containing an $\mathrm{Ag} / \mathrm{AgCl}$ reference electrode, Pt wire auxiliary electrode, and glassy carbonworking electrode with tetrabutylammonium perchlorate as supporting electrolyte. Electron-ionization (EI) mass spectra were recorded by JEOL-GC Mass Spectrometer MATE-2.

2.1. Synthesis of Azo Ligand (CDTMP). The diazonium salt, 5-((4-chlorophenyl)diazenyl)-2-hydroxybenzaldehyde $\left(\mathrm{CPDA}_{Z} \mathrm{HB}\right)$ [13] $(2.3 \mathrm{~g}, 8.7 \mathrm{mmol})$, was condensed with $p$-toluidine $(0.94 \mathrm{~g}, 8.7 \mathrm{mmol})$ in ethanol and refluxed for $3 \mathrm{~h}$. After the reaction was over, the reaction mixture was concentrated to one-half of the volume and refrigerated for one day. The obtained bright orange-colour solid product was filtered and recrystallized from ethanol. The yield obtained was $77 \%$, m.p. $212^{\circ}$ C. (Scheme 1 ).

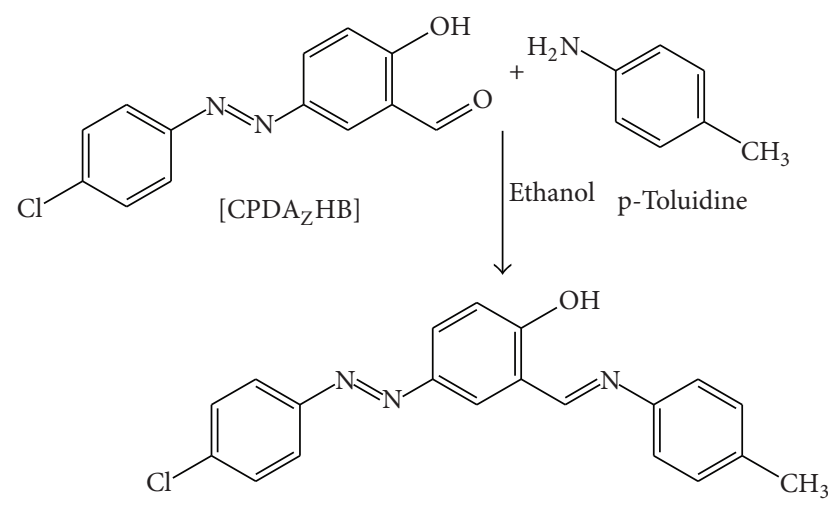

4-((4-Chlorophenyl)diazenyl)-2-(( $p$-tolylimino)methyl)phenol [CDTMP]

Scheme 1: Synthesis of azo Schiff base ligand.

2.2. Synthesis of Metal(II) Complexes. To a solution of $(0.70 \mathrm{~g}, \quad 2 \mathrm{mmol}) \quad 4-((4 \quad$ chlorophenyl $)$ diazenyl $)-2-((p-$ tolylimino)methyl)phenol (CDTMP) in $20 \mathrm{~mL}$ ethanol was added $1 \mathrm{mmol}$ of metal salts $\left(\mathrm{VOSO}_{4} \cdot 5 \mathrm{H}_{2} \mathrm{O}, \mathrm{MnCl}_{2} \cdot 4 \mathrm{H}_{2} \mathrm{O}\right.$, $\mathrm{CoCl}_{2} \cdot 6 \mathrm{H}_{2} \mathrm{O}, \mathrm{NiCl}_{2} \cdot 6 \mathrm{H}_{2} \mathrm{O}, \mathrm{CuCl}_{2} \cdot 2 \mathrm{H}_{2} \mathrm{O}$, and $\left.\mathrm{ZnCl}_{2}\right)$. The solution was stirred for $1 \mathrm{~h}$ at room temperature, and the coloured complexes precipitated upon concentration was filtered, washed with ethanol, and dried under vacuum. The oxovanadium complex was synthesized from the ligand and oxovanadium sulfate by adopting the above method under reflux for $3 \mathrm{~h}$ and concentrating the solution through rotoevaporation. The yield obtained was $60-70 \%$.

\section{Results and Discussion}

The analytical data and physical properties of CDTMP and metal(II) complexes are presented in Table 1. The complexes are partially soluble in ethanol, chloroform, and acetonitrile but soluble in polar coordinating solvents such as DMF and DMSO. The molar conductivities of all the complexes are in the $8.9-11.2 \Omega^{-1} \mathrm{~cm}^{2} \mathrm{~mol}^{-1}$ range indicating a nonelectrolytic nature. The obtained data showed that the stoichiometry of the chelates is $1: 2$ ( $\mathrm{M}$ : Ligand) and the analytical data of the complexes are in good agreement with the general formula $\mathrm{ML}_{2}$ for $\mathrm{Cu}(\mathrm{II}), \mathrm{VO}(\mathrm{II})$, and $\mathrm{ML}_{2} \cdot 2 \mathrm{H}_{2} \mathrm{O}$ for $\mathrm{Mn}(\mathrm{II})$, $\mathrm{Ni}(\mathrm{II}), \mathrm{Co}(\mathrm{II})$, and $\mathrm{Zn}(\mathrm{II})$ complexes.

3.1. Mass Spectral Studies. The mass spectra of the ligand CDTMP $\left(\mathbf{L}_{\mathbf{1}}\right)$ and its complexes were recorded at room temperature, and they are used to compare their stoichiometry composition. The azo Schiff base shows a molecular ion peak at $349 \mathrm{~m} / z$. Molecular ion peak for the nickel complex observed at $790 \mathrm{~m} / z$ confirms the stoichiometry of metal chelates as $\left[\mathrm{ML}_{2} \cdot 2 \mathrm{H}_{2} \mathrm{O}\right]$ type, whereas the molecular ion peak for the $\mathrm{Cu}$ (II) and $\mathrm{VO}$ (II) complexes observed at $\mathrm{m} / z$ 759, 764 confirms the stoichiometry of metal chelates as $\left[\mathrm{ML}_{2}\right]$ type. The mass spectra of the ligand and its nickel(II) complex are shown in Figure 1. 
TABLE 1: Physical characterization, analytical and molar conductance data of the ligand (CDTMP, $\mathbf{L}_{\mathbf{1}}$ ), and its metal(II) complexes.

\begin{tabular}{|c|c|c|c|c|c|c|c|}
\hline \multirow{2}{*}{ Compound } & \multirow{2}{*}{$\mathrm{FW}\left(\mathrm{g} / \mathrm{mol}^{-1}\right)$} & \multicolumn{4}{|c|}{ Found (Calcd) (\%) } & \multirow{2}{*}{ m.p. $\left({ }^{\circ} \mathrm{C}\right)$} & \multirow{2}{*}{$\Lambda_{\mathrm{M}}\left(\Omega^{-1} \mathrm{~cm}^{2} \mathrm{~mol}^{-1}\right)$} \\
\hline & & $\mathrm{M}$ & C & $\mathrm{H}$ & $\mathrm{N}$ & & \\
\hline $\mathrm{C}_{20} \mathrm{H}_{16} \mathrm{ClN}_{3} \mathrm{O}(\mathrm{CDTMP})\left(\mathbf{L}_{\mathbf{1}}\right)$ & 349.10 & - & $\begin{array}{c}68.69 \\
(68.67)\end{array}$ & $\begin{array}{c}4.58 \\
(4.61)\end{array}$ & $\begin{array}{c}12.00 \\
(12.02)\end{array}$ & $212-214$ & - \\
\hline$\left[\mathrm{VO}(\mathrm{CDTMP})_{2}\right]\left(\mathbf{L}_{\mathbf{1}} \mathbf{1}\right)$ & 763.84 & $\begin{array}{c}6.62 \\
(6.66)\end{array}$ & $\begin{array}{c}62.83 \\
(62.84)\end{array}$ & $\begin{array}{c}3.90 \\
(3.92)\end{array}$ & $\begin{array}{c}10.97 \\
(10.99)\end{array}$ & $285-287$ & 10.8 \\
\hline$\left[\mathrm{Mn}(\mathrm{CDTMP})_{2} \cdot 2 \mathrm{H}_{2} \mathrm{O}\right]\left(\mathbf{L}_{\mathbf{1}} \mathbf{2}\right)$ & 787.16 & $\begin{array}{c}6.98 \\
(6.97)\end{array}$ & $\begin{array}{c}60.94 \\
(60.92)\end{array}$ & $\begin{array}{c}4.36 \\
(4.35)\end{array}$ & $\begin{array}{c}10.63 \\
(10.66)\end{array}$ & $282-284$ & 8.9 \\
\hline$\left[\mathrm{Co}(\mathrm{CDTMP})_{2} \cdot 2 \mathrm{H}_{2} \mathrm{O}\right]\left(\mathbf{L}_{\mathbf{1}} \mathbf{3}\right)$ & 791.15 & $\begin{array}{c}7.45 \\
(7.44)\end{array}$ & $\begin{array}{c}60.59 \\
(60.61)\end{array}$ & $\begin{array}{c}4.30 \\
(4.32)\end{array}$ & $\begin{array}{c}10.61 \\
(10.60)\end{array}$ & $312-314$ & 11.9 \\
\hline$\left[\mathrm{Ni}(\mathrm{CDTMP})_{2} \cdot 2 \mathrm{H}_{2} \mathrm{O}\right]\left(\mathbf{L}_{\mathbf{1}} \mathbf{4}\right)$ & 790.14 & $\begin{array}{c}7.40 \\
(7.41)\end{array}$ & $\begin{array}{c}60.61 \\
(60.63)\end{array}$ & $\begin{array}{c}4.31 \\
(4.33)\end{array}$ & $\begin{array}{c}10.64 \\
(10.61)\end{array}$ & $287-289$ & 9.6 \\
\hline$\left[\mathrm{Cu}(\mathrm{CDTMP})_{2}\right]\left(\mathbf{L}_{\mathbf{1}} \mathbf{5}\right)$ & 759.11 & $\begin{array}{c}8.33 \\
(8.35)\end{array}$ & $\begin{array}{c}63.13 \\
(63.12)\end{array}$ & $\begin{array}{c}3.91 \\
(3.94)\end{array}$ & $\begin{array}{c}11.03 \\
(11.04)\end{array}$ & $298-300$ & 10.5 \\
\hline$\left[\mathrm{Zn}(\mathrm{CDTMP})_{2} \cdot 2 \mathrm{H}_{2} \mathrm{O}\right]\left(\mathbf{L}_{\mathbf{1}} \mathbf{6}\right)$ & 796.07 & $\begin{array}{c}8.19 \\
(8.18)\end{array}$ & $\begin{array}{c}60.12 \\
(60.13)\end{array}$ & $\begin{array}{c}4.27 \\
(4.29)\end{array}$ & $\begin{array}{c}10.53 \\
(10.52)\end{array}$ & $305-307$ & 9.9 \\
\hline
\end{tabular}

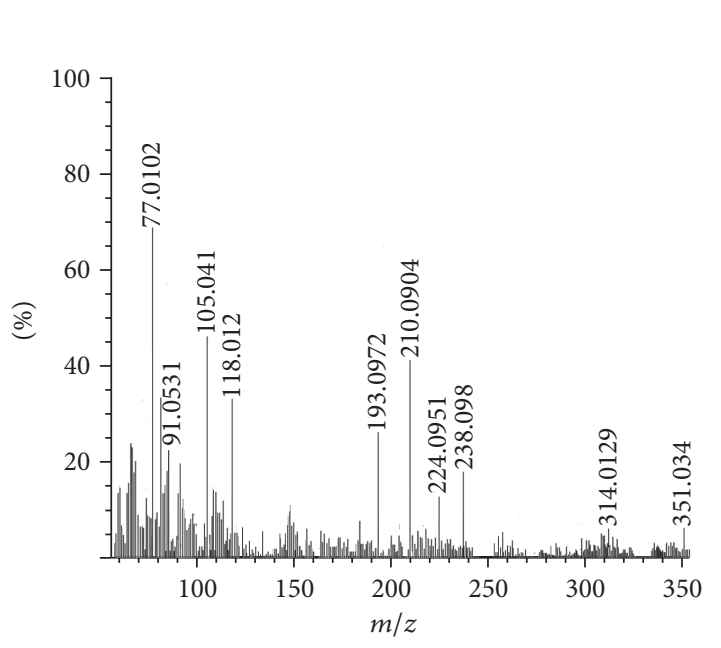

(a)

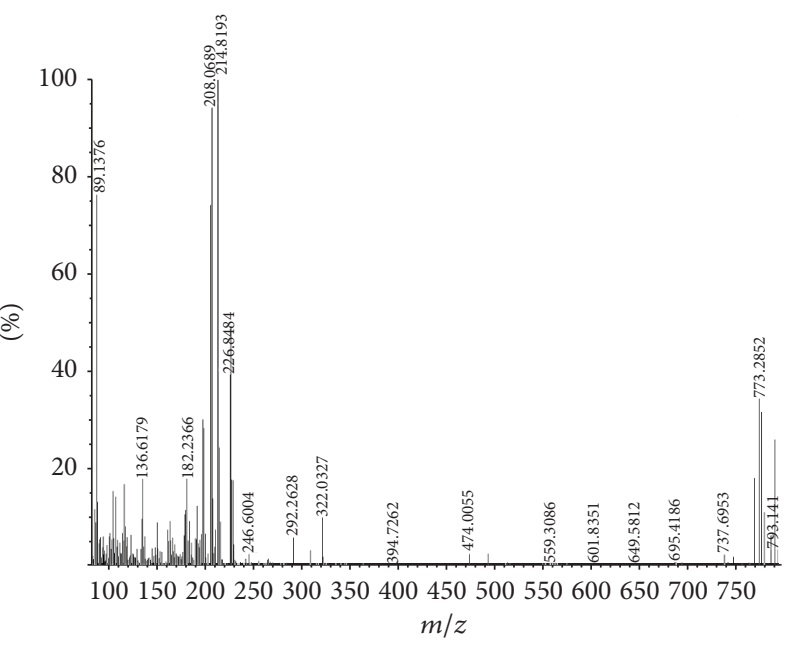

(b)

Figure 1: Mass spectra of (a) [CDTMP], (b) [Ni(CDTMP) $\left.)_{2} \cdot 2 \mathrm{H}_{2} \mathrm{O}\right]$.

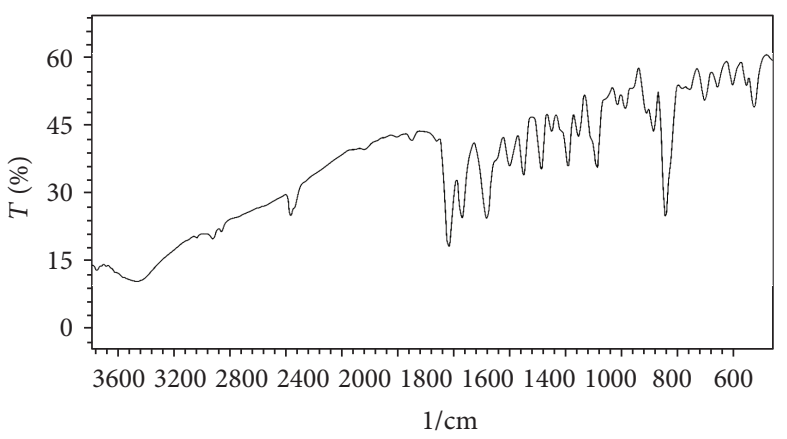

(a)

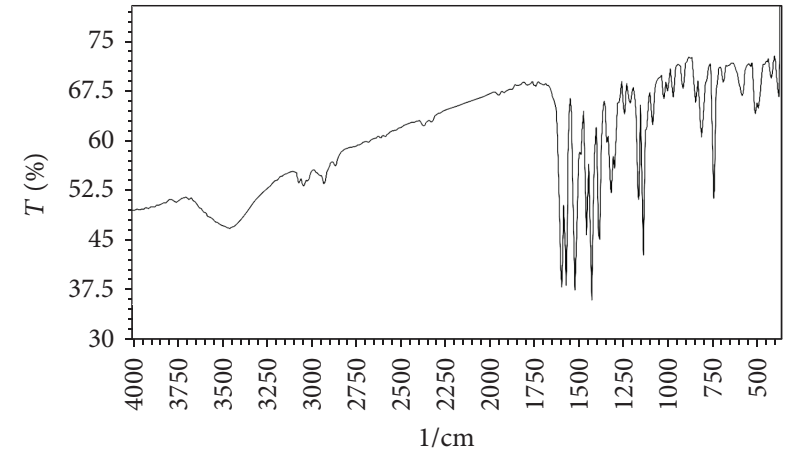

(b)

FIGURE 2: IR spectra of (a) [CDTMP], (b) $\left[\mathrm{Co}(\mathrm{CDTMP})_{2} \cdot 2 \mathrm{H}_{2} \mathrm{O}\right]$. 
TABLE 2: IR spectral data of [CDTMP] and its metal(II) complexes $\left(\mathrm{cm}^{-1}\right)$.

\begin{tabular}{|c|c|c|c|c|c|}
\hline Compound & $v(\mathrm{C}=\mathrm{N})$ & $v(\mathrm{C}-\mathrm{O})$ phenolic & $v(\mathrm{~N}=\mathrm{N})$ & $v(\mathrm{M}-\mathrm{N})$ & $v(\mathrm{M}-\mathrm{O})$ \\
\hline $\mathrm{C}_{20} \mathrm{H}_{16} \mathrm{ClN}_{3} \mathrm{O}(\mathrm{CDTMP})\left(\mathbf{L}_{\mathbf{1}}\right)$ & 1616 & 1284 & 1483 & - & - \\
\hline$\left[\mathrm{VO}(\mathrm{CDTMP})_{2}\right]\left(\mathbf{L}_{\mathbf{1}} \mathbf{1}\right)$ & 1607 & 1309 & 1482 & 536 & 461 \\
\hline$\left[\mathrm{Mn}(\mathrm{CDTMP})_{2} \cdot 2 \mathrm{H}_{2} \mathrm{O}\right]\left(\mathbf{L}_{\mathbf{1}} \mathbf{2}\right)$ & 1601 & 1312 & 1483 & 567 & 452 \\
\hline$\left[\mathrm{Co}(\mathrm{CDTMP})_{2} \cdot 2 \mathrm{H}_{2} \mathrm{O}\right]\left(\mathbf{L}_{\mathbf{1}} \mathbf{3}\right)$ & 1602 & 1305 & 1481 & 594 & 430 \\
\hline$\left[\mathrm{Ni}(\mathrm{CDTMP})_{2} \cdot 2 \mathrm{H}_{2} \mathrm{O}\right]\left(\mathbf{L}_{\mathbf{1}} \mathbf{4}\right)$ & 1608 & 1317 & 1483 & 590 & 425 \\
\hline$\left[\mathrm{Cu}(\mathrm{CDTMP})_{2}\right]\left(\mathbf{L}_{\mathbf{1}} \mathbf{5}\right)$ & 1606 & 1300 & 1482 & 584 & 490 \\
\hline$\left[\mathrm{Zn}(\mathrm{CDTMP})_{2} \cdot 2 \mathrm{H}_{2} \mathrm{O}\right]\left(\mathbf{L}_{\mathbf{1}} \mathbf{6}\right)$ & 1600 & 1295 & 1482 & 525 & 450 \\
\hline
\end{tabular}

3.2. IR Spectral Studies. The characteristic IR spectral data of the ligand and its complexes are given in Table 2. The detected band at $1616 \mathrm{~cm}^{-1}$ is assigned to the stretching vibration of the azomethine group of the ligand CDTMP. This band is shifted in the complexes toward lower frequencies $\left(1608-1600 \mathrm{~cm}^{-1}\right)$ because of the participation of the nitrogen atom to coordinate with metal ion. This fact can be explained by the withdrawing of electrons from nitrogen atom to the metal ion due to coordination process [14]. The bands around $3130 \mathrm{~cm}^{-1}$ and $1284 \mathrm{~cm}^{-1}$ are assigned to $(\mathrm{O}-\mathrm{H})$ vibration and the phenolic $\mathrm{C}-\mathrm{O}$ vibration, respectively. However, in the spectra of the metal complexes the $\mathrm{C}-\mathrm{O}$ bands underwent a shift towards higher frequencies $33 \mathrm{~cm}^{-1}$, and this shift confirms the participation of oxygen in the $\mathrm{C}-\mathrm{O}-\mathrm{M}$ bond. $\mathrm{Mn}(\mathrm{II}), \mathrm{Co}(\mathrm{II}), \mathrm{Ni}(\mathrm{II})$, and $\mathrm{Zn}$ (II) complexes show a broadband at $\sim 3400 \mathrm{~cm}^{-1}$ due to the vibrations of coordinated water molecules [15]. The band at $1483 \mathrm{~cm}^{-1}$ is assigned to the stretching vibration of the diazo group of the azo-linked Schiff base ligand, and the spectra of the complexes did not show any frequency shift of the $-\mathrm{N}=\mathrm{N}-$ band, which may be explained by nonparticipation of azo group in complex formation [16]. The band of medium intensity observed for the complexes in the region $525-594 \mathrm{~cm}^{-1}$ is attributed to $v(\mathrm{M}-\mathrm{N})$ and in the region $425-490 \mathrm{~cm}^{-1}$ to $v(\mathrm{M}-\mathrm{O})$ [17]. All the IR data of the Schiff base and its metal complexes imply that the Schiff base behaves as bidentate and is bonded to the metal ion through phenolic oxygen and imino nitrogen of azomethine group. The IR spectra of the ligand and cobalt complex are depicted in Figure 2.

3.3. ${ }^{1} H$-NMR Spectral Studies. The ${ }^{1} \mathrm{H}-\mathrm{NMR}$ spectrum of CDTMP $\left(\mathbf{L}_{\mathbf{1}}\right)$ recorded in $\mathrm{CDCl}_{3}$ is assigned as follows: the characteristic singlet at $(8.23 \delta)$ is due to the azomethine proton $(-\mathrm{CH}=\mathrm{N})$, and multiplets around $(7.4-7.8 \delta)$ are assigned to aromatic protons, and signal at $(2.31 \delta)$ is ascribed to methyl group. A singlet at $(10.1 \delta)$ is attributed to the phenolic -OH of the Schiff base. The absence of this peak noted for the zinc(II) complex indicates deprotonation of the ligand and coordination to the metal. The azomethine protons signal in the spectrum of the zinc complex is shifted downfield $(8.31 \delta)$ compared to the free ligand, suggesting deshielding of the azomethine group due to the coordination with metal ion. There is no appreciable change in other signals

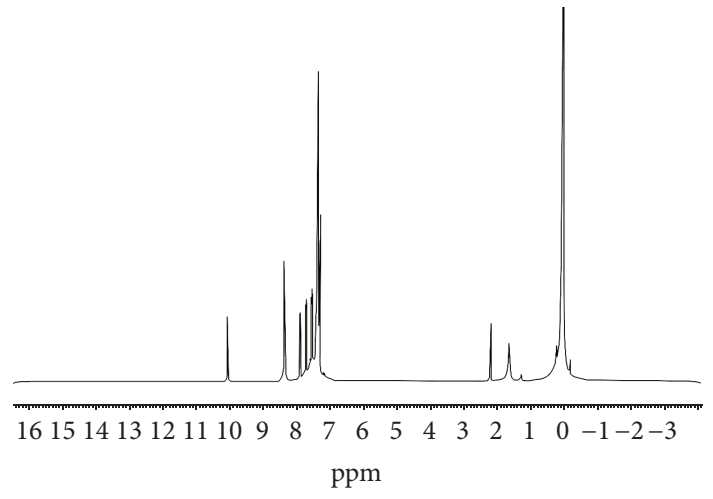

FIGURE $3:{ }^{1} \mathrm{H}$ NMR spectrum of [CDTMP].

of this complex. ${ }^{1} \mathrm{H}$ NMR spectrum of CDTMP is shown in Figure 3.

3.4. Electronic Spectral and Magnetic Susceptibility Studies. The electronic spectra of CDTMP $\left(\mathbf{L}_{\mathbf{1}}\right)$ and its complexes were recorded in DMSO. The absorption spectrum of the ligand shows strong peaks at 26100 and $33670 \mathrm{~cm}^{-1}$ which may be assigned to $n \rightarrow \pi^{*}$ (transitions of the $-\mathrm{CH}=\mathrm{N}-$ and $-\mathrm{N}=\mathrm{N}-$ groups) and $\pi \rightarrow \pi^{*}$ (transition of $-\mathrm{N}=\mathrm{N}-$ azo group) transitions, respectively. The spectral data of the ligand and its complexes with molar extinction coefficient or molar absorption coefficient $\varepsilon\left(\mathrm{L} \mathrm{mol}^{-1} \mathrm{~cm}^{-1}\right)$ are calculated and given in Table 4.

The UV-Vis spectrum of the vanadyl(II) complex $\left(\mathbf{L}_{\mathbf{1}} \mathbf{1}\right)$ exhibits three d-d bands observed at 12013, 17182, and $24128 \mathrm{~cm}^{-1}$ assignable to ${ }^{2} \mathrm{~B}_{2} \rightarrow{ }^{2} \mathrm{E},{ }^{2} \mathrm{~B}_{2} \rightarrow{ }^{2} \mathrm{~B}_{1}$, and ${ }^{2} \mathrm{~B}_{2} \rightarrow{ }^{2} \mathrm{~A}_{1}$ transitions which are the characteristic of square-pyramidal geometry, and the magnetic moment value 1.75 B.M. [18] and the molar extinction coefficient $(\varepsilon)$ values also support the geometry. The electronic absorption spectrum of the $\mathrm{Co}(\mathrm{II})$ complex $\left(\mathbf{L}_{\mathbf{1}} \mathbf{3}\right)$ exhibits three d-d bands at $9267 \mathrm{~cm}^{-1}, 11560 \mathrm{~cm}^{-1}$, and $18115 \mathrm{~cm}^{-1}$ assignable to ${ }^{4} \mathrm{~T}_{1 \mathrm{~g}}(\mathrm{~F}) \rightarrow{ }^{4} \mathrm{~T}_{2 \mathrm{~g}}(\mathrm{~F})\left(v_{1}\right),{ }^{4} \mathrm{~T}_{1 \mathrm{~g}}(\mathrm{~F}) \rightarrow{ }^{4} \mathrm{~A}_{2 \mathrm{~g}}(\mathrm{~F})\left(v_{2}\right)$, and ${ }^{4} \mathrm{~T}_{1 \mathrm{~g}}(\mathrm{~F}) \rightarrow{ }^{4} \mathrm{~T}_{2 \mathrm{~g}}(\mathrm{P})\left(v_{3}\right)$ transitions [19], respectively, and the magnetic moment value of the cobalt(II) complex 4.82 B.M. confirms the octahedral geometry [20]. The molar intensities are in the range of hundreds indicating the strong metalligand interactions. 
TABLE 3

\begin{tabular}{lc}
\hline For Co(II) complexes & For Ni(II) complexes \\
\hline $10 \mathrm{Dq}=1 / 2\left[\left(2 v_{1}-v_{3}\right)+\left(v_{3}^{2}+v_{1} v_{3}-v_{1}^{2}\right)^{1 / 2}\right]$ & $10 \mathrm{Dq}=v_{1}$ \\
$15 B=v_{3}-2 v_{1}+10 \mathrm{Dq}$ & $15 B=\left(v_{2}+v_{3}\right)-3 v_{1}$ \\
$\beta=B / B_{0}\left[B_{0}\right.$ (free ion $\left.)=971\right]$ & $\beta=B / B_{0}\left[B_{0}(\right.$ free ion $\left.)=1030\right]$ \\
$\beta_{0}=(1-\beta) \times 100$ & $\beta_{0}=(1-\beta) \times 100$ \\
\hline
\end{tabular}

TABLE 4: Electronic spectral data of [CDTMP] and its metal(II) complexes.

\begin{tabular}{|c|c|c|c|c|}
\hline Compound & $\begin{array}{c}\lambda_{\max }\left(\mathrm{cm}^{-1}\right) \\
\varepsilon\left(\mathrm{L} \mathrm{mol}^{-1} \mathrm{~cm}^{-1}\right)\end{array}$ & Transition & Geometry & $\mu_{\mathrm{eff}}$ (B.M.) \\
\hline $\operatorname{CDTMP}\left(\mathbf{L}_{1}\right)$ & $\begin{array}{c}26100(610) \\
33670(5900)\end{array}$ & $\begin{array}{l}n \rightarrow \pi^{*} \\
\pi \rightarrow \pi^{*}\end{array}$ & - & - \\
\hline$\left[\mathrm{VO}(\mathrm{CDTMP})_{2}\right]\left(\mathbf{L}_{\mathbf{1}} \mathbf{1}\right)$ & $\begin{array}{l}12013(121) \\
17182(234) \\
24128(510) \\
\end{array}$ & $\begin{aligned}{ }^{2} \mathrm{~B}_{2} & \rightarrow{ }^{2} \mathrm{E} \\
{ }^{2} \mathrm{~B}_{2} & \rightarrow{ }^{2} \mathrm{~B}_{1} \\
{ }^{2} \mathrm{~B}_{2} & \rightarrow{ }^{2} \mathrm{~A}_{1}\end{aligned}$ & Square pyramidal & 1.75 \\
\hline$\left[\mathrm{Co}(\mathrm{CDTMP})_{2} \cdot 2 \mathrm{H}_{2} \mathrm{O}\right]\left(\mathbf{L}_{\mathbf{1}} \mathbf{3}\right)$ & $\begin{array}{c}9267(199) \\
11560(175) \\
18115(392)\end{array}$ & $\begin{array}{l}{ }^{4} \mathrm{~T}_{1 \mathrm{~g}}(\mathrm{~F}) \rightarrow{ }^{4} \mathrm{~T}_{2 \mathrm{~g}}(\mathrm{~F}) \\
{ }^{4} \mathrm{~T}_{1 \mathrm{~g}}(\mathrm{~F}) \rightarrow{ }^{4} \mathrm{~A}_{2 \mathrm{~g}}(\mathrm{~F}) \\
{ }^{4} \mathrm{~T}_{1 \mathrm{~g}}(\mathrm{~F}) \rightarrow{ }^{4} \mathrm{~T}_{2 \mathrm{~g}}(\mathrm{P})\end{array}$ & Octahedral & 4.82 \\
\hline$\left[\mathrm{Ni}(\mathrm{CDTMP})_{2} \cdot 2 \mathrm{H}_{2} \mathrm{O}\right]\left(\mathbf{L}_{\mathbf{1}} \mathbf{4}\right)$ & $\begin{array}{l}10384(156) \\
15822(113) \\
22883(119)\end{array}$ & $\begin{array}{l}{ }^{3} \mathrm{~A}_{2 \mathrm{~g}}(\mathrm{~F}) \rightarrow{ }^{3} \mathrm{~T}_{2 \mathrm{~g}}(\mathrm{~F}) \\
{ }^{3} \mathrm{~A}_{2 \mathrm{~g}}(\mathrm{~F}) \rightarrow{ }^{3} \mathrm{~T}_{1 \mathrm{~g}}(\mathrm{~F}) \\
{ }^{3} \mathrm{~A}_{2 \mathrm{~g}}(\mathrm{~F}) \rightarrow{ }^{3} \mathrm{~T}_{1 \mathrm{~g}}(\mathrm{P})\end{array}$ & Octahedral & 3.02 \\
\hline$\left[\mathrm{Cu}(\mathrm{CDTMP})_{2}\right]\left(\mathbf{L}_{\mathbf{1}} \mathbf{5}\right)$ & $\begin{array}{l}14265(1100) \\
22573(1800) \\
25706(1845)\end{array}$ & $\begin{array}{c}{ }^{2} \mathrm{~B}_{1 \mathrm{~g}} \rightarrow{ }^{2} \mathrm{~A}_{1 \mathrm{~g}} \\
\mathrm{INCT}^{*} \\
\text { INCT }\end{array}$ & Square planar & 2.01 \\
\hline
\end{tabular}

*Intraligand charge transfer.

The nickel(II) complex $\left(\mathbf{L}_{\mathbf{1}} \mathbf{4}\right)$ exhibits three $\mathrm{d}$-d bands at 10384,15822 , and $22883 \mathrm{~cm}^{-1}$, due to ${ }^{3} \mathrm{~A}_{2 \mathrm{~g}}(\mathrm{~F}) \rightarrow{ }^{3} \mathrm{~T}_{2 \mathrm{~g}}(\mathrm{~F})$ $\left[v_{1}\right],{ }^{3} \mathrm{~A}_{2 \mathrm{~g}}(\mathrm{~F}) \rightarrow{ }^{3} \mathrm{~T}_{1 \mathrm{~g}}(\mathrm{~F})\left[v_{2}\right]$, and ${ }^{3} \mathrm{~A}_{2 \mathrm{~g}}(\mathrm{~F}) \rightarrow{ }^{3} \mathrm{~T}_{1 \mathrm{~g}}(\mathrm{P})$ $\left[v_{3}\right]$ transitions which arises from an octahedral structure [21]. The $\mathrm{Ni}(\mathrm{II})$ complex reported has magnetic moment of 3.02 B.M. which indicates that the $\mathrm{Ni}(\mathrm{II})$ complex is six coordinate and probably octahedral $[22,23]$. The absorption at $14265 \mathrm{~cm}^{-1}$ with high molar intensity $\left(1100 \mathrm{~L} \mathrm{~mol}^{-1} \mathrm{~cm}^{-1}\right)$ of copper(II) complex $\left(\mathbf{L}_{\mathbf{1}} \mathbf{5}\right)$ is tentatively assigned to ${ }^{2} \mathrm{~B}_{1 \mathrm{~g}} \rightarrow{ }^{2} \mathrm{~A}_{1 \mathrm{~g}}$ transition suggesting square planar geometry [24]. An additional band appears at 22573 and $25706 \mathrm{~cm}^{-1}$ which may be due to intraligand charge transfer (INCT) in the UV region, and the molar extinction coefficient (1800, $1845 \mathrm{~L} \mathrm{~mol}^{-1} \mathrm{~cm}^{-1}$ ) of charge transfer transitions is higher than the $\mathrm{d}$ - $\mathrm{d}$ transition. The magnetic moment value 2.01 B.M. falls within the range normally observed for square planar $\mathrm{Cu}(\mathrm{II})$ complexes [25].

The $\mathrm{Zn}(\mathrm{II})$ complex $\left(\mathbf{L}_{\mathbf{1}} \mathbf{6}\right)$ has been found to be diamagnetic in nature. On the basis of analytical, conductance, and spectral data, the $\mathrm{Zn}$ (II) complex of CDTMP is assigned to octahedral geometry [26]. The $\mathrm{Mn}(\mathrm{II})$ complex $\left(\mathbf{L}_{\mathbf{1}} \mathbf{2}\right)$ under study has the magnetic moment value of 5.84 B.M. which supports an octahedral geometry around the metal ion [27]. The ligand-field-splitting energy (10Dq), interelectronic repulsion parameter $(B)$, and covalency factor (nephelauxetic ratio) $(\beta)$ for the octahedral $\mathrm{Co}(\mathrm{II})$ and $\mathrm{Ni}$ (II) complexes have been calculated using the secular equation given by Konig are shown in Table 3 [28].
The ligand-field parameters of $\mathrm{Ni}$ (II) and $\mathrm{Co}(\mathrm{II})$ complexes are shown in Table 5, and the values support the proposed geometry for the synthesized $\mathrm{Ni}$ (II) and $\mathrm{Co}$ (II) octahedral complexes. The covalent factor $\beta$ equal to $B / B^{\prime}$ for the complexes is less than one suggesting considerable amount of covalent character of the metal-ligand bonds.

3.5. Electrochemical Behavior. The redox behavior of the copper(II) complex $\left(\mathbf{L}_{\mathbf{1}} \mathbf{5}\right)$ was performed in DMSO solution at room temperature with tetrabutylammonium perchlorate (TBAP) as supporting electrolyte; glassy carbon as working electrode; Pt wire as auxiliary electrode; $\mathrm{Ag} / \mathrm{AgCl}$ as reference electrode in order to monitor spectral and structural changes accompanying electron transfer. The copper(II) complex exhibited one-step reduction peak at $0.122 \mathrm{~V}$ and two oxidation peaks at 0.812 and $0.352 \mathrm{~V}$ at the scan rate of $100 \mathrm{mV}$ as shown in Figure 4. It has been observed that the $E_{\mathrm{pc}}$ and $E_{\mathrm{pa}}$ values change with scan rate as shown in Table 6 . The $\Delta E_{p}$ values increase with increase in scan rate and is found to be greater than $400 \mathrm{mV}$ which indicates that the nature of the electron transfer process is irreversible [29, 30].

3.6. EPR Spectral Studies. The EPR spectrum of the copper(II) complex $\left(\mathbf{L}_{\mathbf{1}} \mathbf{5}\right)$ was recorded at $300 \mathrm{~K}$ and $77 \mathrm{~K}$, and the spin Hamiltonian parameters of the $\mathrm{Cu}(\mathrm{II})$ complex are listed in Table 7. The observed spectral parameters for this compound are $g_{\perp}=2.07, g_{\|}=2.15$, and $g_{\text {iso }}=2.09$ which are evident that the unpaired electron lies predominantly 
TABLE 5: Electronic parameters of $\mathrm{Ni}(\mathrm{II})$ and $\mathrm{Co}(\mathrm{II})$ complexes.

\begin{tabular}{lccccc}
\hline Compound & $v_{2} / v_{1}$ & $B\left(\mathrm{~cm}^{-1}\right)$ & $\beta$ & $\beta^{\circ}$ & $10 \mathrm{Dq}\left(\mathrm{cm}^{-1}\right)$ \\
\hline$\left[\mathrm{Co}(\mathrm{CDTMP})_{2} \cdot 2 \mathrm{H}_{2} \mathrm{O}\right]\left(\mathbf{L}_{\mathbf{1}} \mathbf{3}\right)$ & 1.25 & 717 & 0.74 & 26 & 10335 \\
{$\left[\mathrm{Ni}(\mathrm{CDTMP})_{2} \cdot 2 \mathrm{H}_{2} \mathrm{O}\right]\left(\mathbf{L}_{\mathbf{1}} \mathbf{4}\right)$} & 1.52 & 567 & 0.55 & 45 & 10384 \\
\hline
\end{tabular}

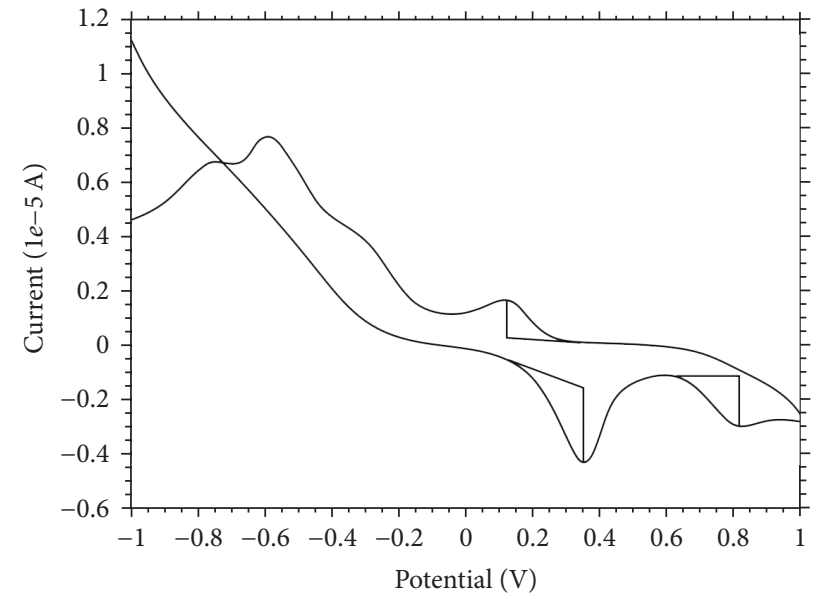

FIgUre 4: Cyclic voltammogram of $\left[\mathrm{Cu}(\mathrm{CDTMP})_{2}\right]$ in DMSO.

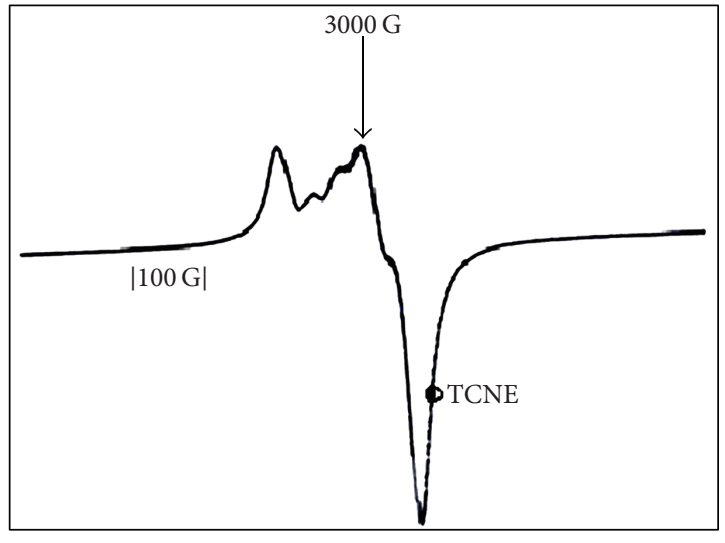

Figure 5: EPR spectrum of $\left[\mathrm{Cu}(\mathrm{CDTMP})_{2}\right]$. in the $d_{X^{2}-Y^{2}}$ orbital as $g_{\|}>g_{\perp}>g_{e}$, and this shows the characteristic of square planar geometry [31]. The $g_{\text {iso }}$ value is less than 2.3 indicating the covalent character of the metal-ligand bond [32]. In the axial spectra, the $g$-values are related with exchange interaction coupling constant $(G)$ by the expression $G=g_{\|}-2.0023 / g_{\perp}-2.0023$. According to Matsubayashi [33], if the value of $G$ is larger than four, the exchange interaction is negligible because the local tetragonal axes are aligned parallel or slightly misaligned. If its value is less than four, the exchange interaction is considerable, and the local tetragonal axes are misaligned. For present copper complex, the $G$ value is 2.1 , which suggests that the exchange interaction is considerable, and the local tetragonal axes are misaligned. The $\alpha^{2}$ values fall in the range 0.72 indicating the presence of appreciable in-plane covalency [34]. The magnetic moment of the copper(II) complex calculated using the relation $\mu^{2}=3 / 4|g|^{2}$ is found to be 2.01 B.M., and the orbital reduction factors $K_{\|}$and $K_{\perp}$ were estimated from the expression $K_{\|}=\left(g_{\|}-2.0023\right) \Delta E / 8 \lambda, K_{\perp}=\left(g_{\|}-\right.$ 2.0023) $\Delta E / 2 \lambda, \lambda=-828 \mathrm{~cm}^{-1}$ (spin-orbit coupling constant for the free ion). For this complex, the observed order $K_{\|}$ $(0.32)<K_{\perp}(0.46)$ implying the presence of in-plane $\pi$ bonding. The EPR spectrum is shown in Figure 5.

Based on the previous discussions such as elemental analysis, molar conductance, EI mass, IR, magnetic susceptibility measurements, and electronic and EPR spectral studies, the following structure may be proposed for the complexes. The synthesized azo-azomethine ligand was coordinated to the metal ion through the azomethine nitrogen and oxygen atom of the hydroxyl group in salicylaldehyde. The geometry around the $\mathrm{Cu}$ (II) complex is square planar, $\mathrm{VO}(\mathrm{II})$ is square pyramidal, and the other metal(II) ion is in octahedral geometry and depicted in Scheme 2.

3.7. Biological Activities. The antimicrobial activity of the azo Schiff base compound CDTMP and its complexes were tested in vitro by the well diffusion method [35] against the bacterial strains (Pseudomonas aeruginosa, Escherichia coli, and Staphylococcus aureus) and the fungal strains (Candida albicans and Aspergillus niger). Amikacin and Ketoconozole were used as reference compounds for antibacterial and antifungal activities, respectively. Stock solution $\left(10^{-3} \mathrm{M}\right)$ was prepared by dissolving the compounds in DMSO. The diameter of the inhibition zones was measured in millimeters. Antimicrobial activities were performed in triplicate, and the average was taken as the final reading. The growth of inhibition zones after incubation is shown in Table 8 and Figure 6.

The observed result indicates that most of the complexes have higher activity than the free ligand. Such increased activity of the complexes can be explained on the basis of Overtone's concept [36] and Tweedy's Chelation theory [37]. Among the complexes, copper complex was found to be the most active and could inhibit the fungal growth at higher concentration. The greater activity of $\mathrm{Cu}$ (II) complex can be explained on the basis of their particle size [38]. From scanning electron microscopy it is clear that copper complex has nanoparticle size. This smaller size may be the reason for increased biological activity. It has been suggested that the mode of action of the compounds may involve the formation of hydrogen bond through azomethine group with the active center of cell constituents resulting in interference with normal cell process. These complexes also disturb the respiration process of the cell and thus block the synthesis of the proteins that restricts further growth of the organism. 
TABLE 6: Redox potential of $\left[\mathrm{Cu}(\mathrm{CDTMP})_{2}\right]$ at different scan rates.

\begin{tabular}{lcccc}
\hline Compound & Scan rate $(\mathrm{mV})$ & $E_{\mathrm{pc}}(\mathrm{V})$ & $E_{\mathrm{pa}}(\mathrm{V})$ & 0.812 \\
& 100 & 0.122 & 0.352 & $\Delta E_{p}(\mathrm{~V})$ \\
{$\left[\mathrm{Cu}(\mathrm{CDTMP})_{2}\right]\left(\mathbf{L}_{\mathbf{1}} \mathbf{5}\right)$} & 150 & 0.105 & 0.862 & 0.690 \\
& 200 & 0.092 & 0.809 & 0.757 \\
\hline
\end{tabular}

TABLE 7: EPR spectral parameters of $\left[\mathrm{Cu}(\mathrm{CDTMP})_{2}\right]$.

\begin{tabular}{|c|c|c|c|c|c|c|c|c|c|c|c|c|}
\hline Compound & $\mathcal{g}_{\|}$ & $g_{\perp}$ & $g_{\text {iso }}$ & $\alpha^{2}$ & $\beta^{2}$ & $\begin{array}{c}A_{\|} \\
10^{-4} \mathrm{~cm}^{-1}\end{array}$ & $\begin{array}{c}A_{\perp} \\
10^{-4} \mathrm{~cm}^{-1}\end{array}$ & $\begin{array}{c}A_{\text {iso }} \\
10^{-4} \mathrm{~cm}^{-1}\end{array}$ & $g_{\|} / A_{\|} \mathrm{cm}$ & $K_{\|}$ & $K_{\perp}$ & $\mu$ (B.M.) \\
\hline $\begin{array}{l}{\left[\mathrm{Cu}(\mathrm{CDTMP})_{2}\right]} \\
\left(\mathbf{L}_{\mathbf{1}} \mathbf{5}\right)\end{array}$ & 2.15 & 2.07 & 2.09 & 0.72 & 0.28 & 175 & 98 & 124 & 122 & 0.32 & 0.46 & 2.01 \\
\hline
\end{tabular}

TABLE 8: The in vitro antimicrobial activity of [CDTMP] and its metal(II) complexes*.

\begin{tabular}{|c|c|c|c|c|c|c|}
\hline \multirow{2}{*}{ Compound } & \multirow{2}{*}{ Concentration $\left(\mu \mathrm{gmL}^{-1}\right)$} & \multicolumn{5}{|c|}{ Zone of inhibition (in $\mathrm{mm}$ ) } \\
\hline & & E. coli & S. aureus & P. aeruginosa & A. niger & C. albicans \\
\hline \multirow{3}{*}{$\operatorname{CDTMP}\left(\mathbf{L}_{\mathbf{1}}\right)$} & 5 & 9 & 9 & 10 & $\mathrm{R}$ & 8 \\
\hline & 10 & 13 & 10 & 12 & 9 & 12 \\
\hline & 15 & 10 & 12 & $\mathrm{R}$ & 11 & 9 \\
\hline \multirow{3}{*}[\mathrm{VO}(\mathrm{CDTMP})_{2}]{$\left(\mathbf{L}_{\mathbf{1}} \mathbf{1}\right)$} & 5 & 16 & $\mathrm{R}$ & 14 & 15 & 16 \\
\hline & 10 & 19 & 20 & 19 & 20 & 19 \\
\hline & 15 & 25 & 27 & 22 & 26 & 27 \\
\hline \multirow{3}{*}[\mathrm{Mn}(\mathrm{CDTMP})_{2}\cdot2\mathrm{H}_{2}\mathrm{O}]{$\left(\mathbf{L}_{\mathbf{1}} \mathbf{2}\right)$} & 5 & 8 & 10 & 18 & 9 & $\mathrm{R}$ \\
\hline & 10 & 14 & 21 & $\mathrm{R}$ & 11 & $\mathrm{R}$ \\
\hline & 15 & $\mathrm{R}$ & $\mathrm{R}$ & 11 & $\mathrm{R}$ & $\mathrm{R}$ \\
\hline \multirow{3}{*}[\mathrm{Co}(\mathrm{CDTMP})_{2}\cdot2\mathrm{H}_{2}\mathrm{O}]{$\left(\mathbf{L}_{\mathbf{1}} \mathbf{3}\right)$} & 5 & $\mathrm{R}$ & 18 & 16 & 10 & 11 \\
\hline & 10 & 19 & 25 & 24 & 12 & 18 \\
\hline & 15 & 24 & 29 & 27 & 21 & 23 \\
\hline \multirow{3}{*}[\mathrm{Ni}(\mathrm{CDTMP})_{2}\cdot2\mathrm{H}_{2}\mathrm{O}]{$\left(\mathbf{L}_{\mathbf{1}} \mathbf{4}\right)$} & 5 & $\mathrm{R}$ & 12 & $\mathrm{R}$ & 14 & 11 \\
\hline & 10 & 17 & 21 & 17 & 17 & 14 \\
\hline & 15 & 10 & 24 & 24 & 25 & 20 \\
\hline \multirow{3}{*}[\mathrm{Cu}(\mathrm{CDTMP})_{2}]{$\left(\mathbf{L}_{\mathbf{1}} \mathbf{5}\right)$} & 5 & 21 & 20 & 21 & 20 & 23 \\
\hline & 10 & 26 & 31 & 23 & 31 & 25 \\
\hline & 15 & 27 & 33 & 26 & 32 & 29 \\
\hline \multirow{3}{*}[\mathrm{Zn}(\mathrm{CDTMP})_{2}\cdot2\mathrm{H}_{2}\mathrm{O}]{$\left(\mathbf{L}_{\mathbf{1}} \mathbf{6}\right)$} & 5 & 7 & 5 & 7 & 7 & 5 \\
\hline & 10 & 12 & 10 & 10 & 10 & 7 \\
\hline & 15 & 15 & 20 & 15 & 12 & 15 \\
\hline \multirow{3}{*}{ Standard } & 5 & 5 & 5 & 5 & 2 & 2 \\
\hline & 10 & 7 & 7 & 7 & 5 & 5 \\
\hline & 15 & 9 & 9 & 9 & 7 & 7 \\
\hline
\end{tabular}

Standard (Amikacin and Ketoconozole). ${ }^{*}$ Zone of inhibition in mm. Each value observed is within the error limits of \pm 2 . R: resistant.

TABLE 9: Fluorescence parameters of [CDTMP] and its metal(II) complexes.

\begin{tabular}{lccc}
\hline Compound & Excitation wavelength $\lambda_{\max }(\mathrm{nm})$ & Emission wavelength $\lambda_{\max }(\mathrm{nm})$ & Quantum yield $(\varphi f)$ \\
\hline $\mathrm{CDTMP}\left(\mathbf{L}_{\mathbf{1}}\right)$ & 353 & 376 & 0.721 \\
{$\left[\mathrm{VO}(\mathrm{CDTMP})_{2}\right]\left(\mathbf{L}_{\mathbf{1}} \mathbf{1}\right)$} & 799 & 804 & 0.880 \\
{$\left[\mathrm{Co}(\mathrm{CDTMP})_{2} \cdot 2 \mathrm{H}_{2} \mathrm{O}\right]\left(\mathbf{L}_{\mathbf{1}} \mathbf{3}\right)$} & 440 & 462 & 0.994 \\
{$\left[\mathrm{Ni}(\mathrm{CDTMP})_{2} \cdot 2 \mathrm{H}_{2} \mathrm{O}\right]\left(\mathbf{L}_{\mathbf{1}} \mathbf{4}\right)$} & 566 & 601 & 0.053 \\
{$\left[\mathrm{Cu}(\mathrm{CDTMP})_{2}\right]\left(\mathbf{L}_{\mathbf{1}} \mathbf{5}\right)$} & 426 & 496 & 0.062 \\
\hline
\end{tabular}




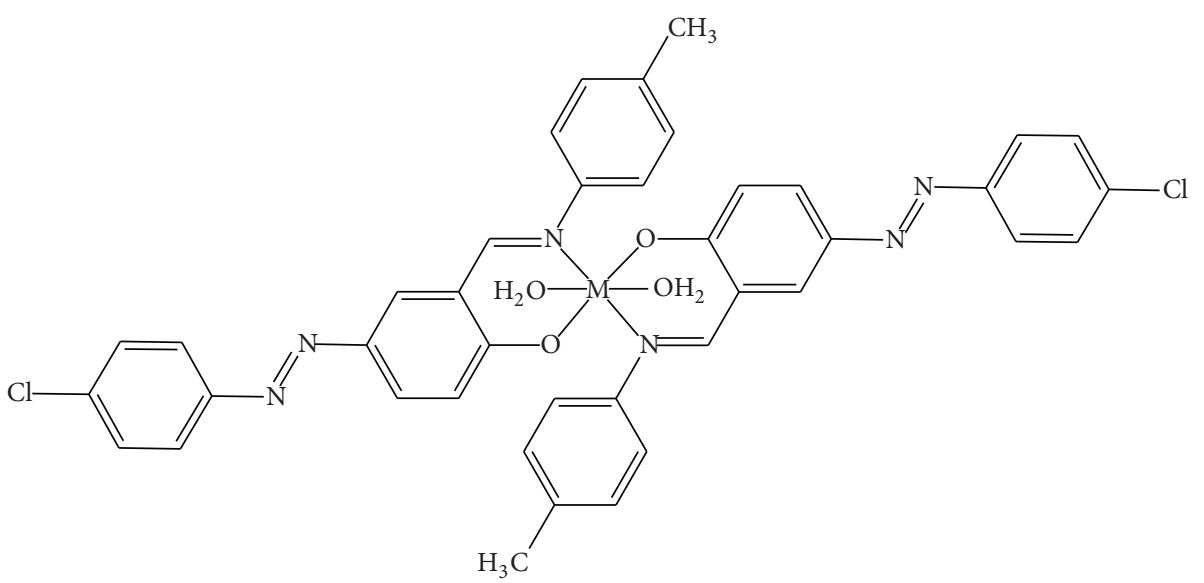

$\mathrm{M}=\mathrm{Mn}(\mathrm{II}), \mathrm{Co}(\mathrm{II}), \mathrm{Ni}(\mathrm{II})$ and $\mathrm{Zn}(\mathrm{II})$
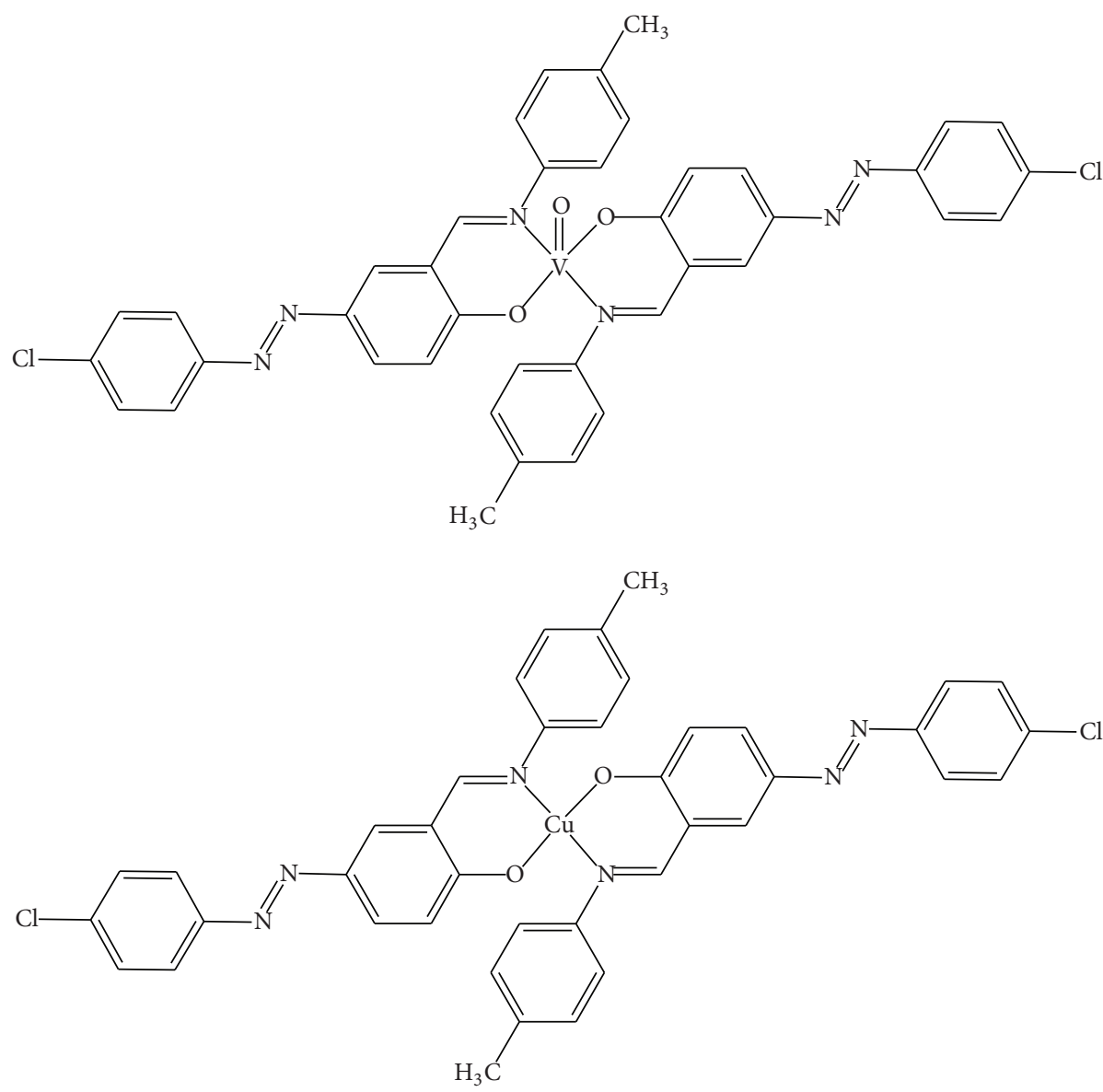

SCHEMe 2: Geometry of the metal(II) complexes.

3.8. Fluorescence Studies. The photoluminescence properties of CDTMP and their complexes were studied at room temperature, and the data are reported in Table 9. The excitation spectra of ligand show a maximum at $353 \mathrm{~nm}$ and an emission maximum at $\lambda_{\mathrm{em}}=376 \mathrm{~nm}$. The metal(II) complexes show strong fluorescence with high-quantum yield, and the excitation at $426-799 \mathrm{~nm}$ gives an emission at $442-804 \mathrm{~nm}$, assigned to $\pi-\pi^{*}$ intraligand fluorescence $[39,40]$. Emission intensity of the metal(II) complexes is higher than that of free ligands, and the enhanced fluorescence efficiency of the complexes is attributed to coordination increasing the rigidity, thereby reducing energy loss by thermal vibration 

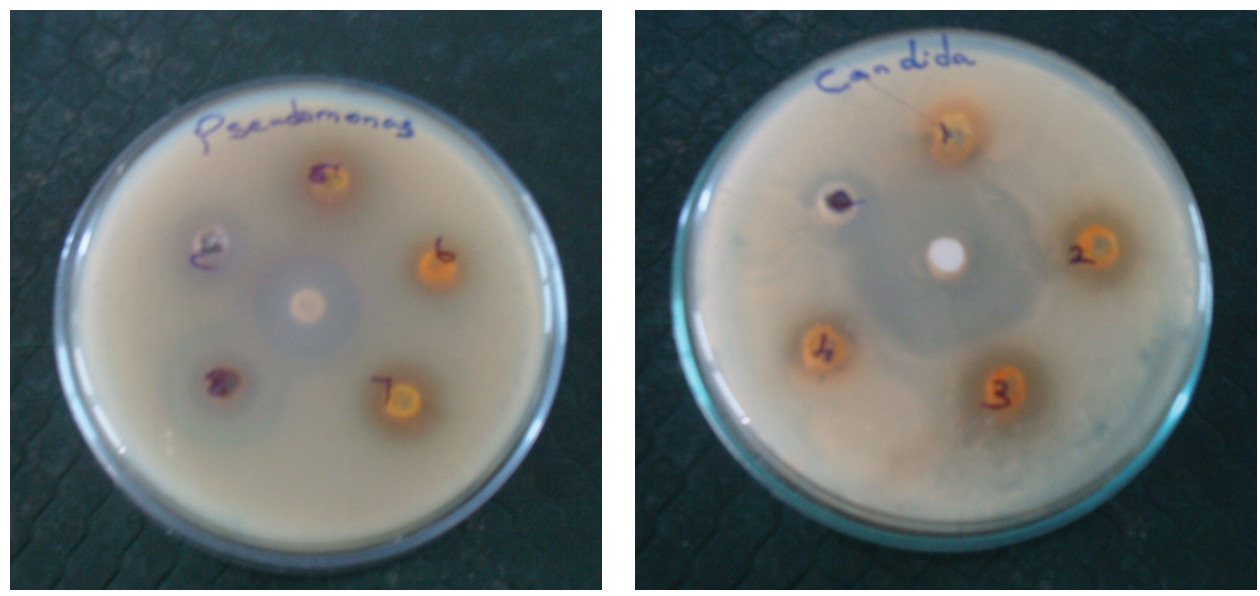

FIgURE 6: The inhibition zones formed for Pseudomonas aeruginosa and Candida albicans.

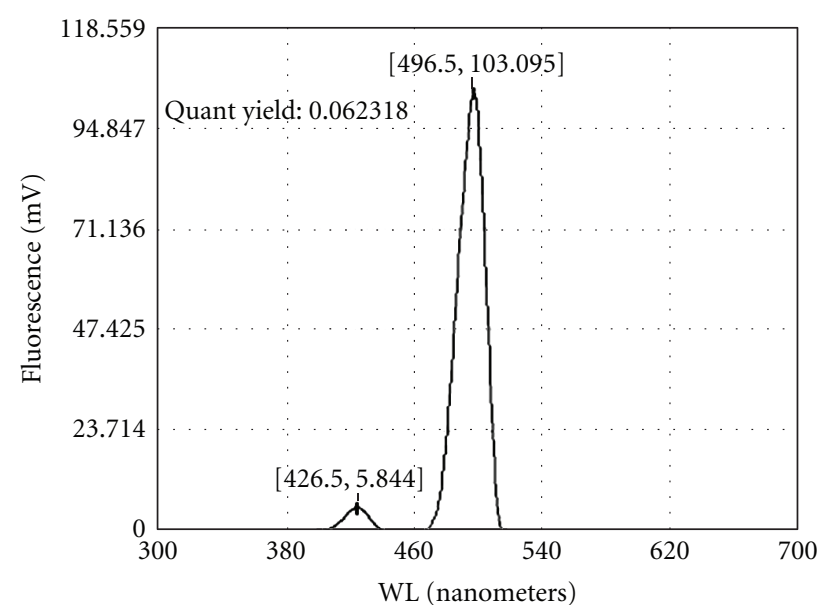

Figure 7: Fluorescence spectrum of $\left[\mathrm{Cu}(\mathrm{CDTMP})_{2}\right]$.

decay [41]. Introduction of the substituent on the azo ligand has an interesting effect on the intensity of emission spectra. The fluorescence quantum yields [42] of the ligand and its complexes were also obtained. From this fluorescence study it is evident that these azo compounds might possess potential molecular sensing or photoconductive applications. Fluorescence spectrum of copper(II) complex is depicted in Figure 7.

3.9. NLO Property. The recent recognition is that the organic materials with conjugated $\pi$-electron systems exhibit extremely large optical nonlinear responses, and this leads to rapid growth of interest in a field which is currently dominated by inorganic materials [43]. The SHG (second harmonic generation) efficiency of the azo compound (CDTMP) was determined by modified version of powder technique developed by Kurtz and Perry [44]. The efficiency of the sample was compared with microcrystalline powder of KDP and urea. The input energy used in this particular setup is $2.2 \mathrm{~mJ} /$ pulse. Azo Schiff base shows the better second harmonic efficiency than urea and KDP. 4-((4Chlorophenyl)diazenyl)-2-(( $p$-tolylimino)methyl)phenol shows 1.6 and 3.9 times more activity than urea and KDP, respectively.

The electron-pull and electron-push substituents on the benzene rings have much influence on the electronic structure of azo compounds. The conjugative and induction effects of $\mathrm{Cl}$ atom as electron-pull groups and $\mathrm{CH}_{3}$ as electron-push groups make electron density on the benzene rings change, and the band of $\mathrm{N}=\mathrm{N}$ become an effective electronic passage. The delocatized $\pi$-electron distribution of the azo dye makes it possible to possess a larger nonlinear optical susceptibility.

3.10. Scanning Electron Microscopy. The morphology and particle size of the Schiff base metal complex have been illustrated by the scanning electron micrograph (SEM). SEM uses a focused beam of high-energy electrons to generate a variety of signals from the surface of a solid specimen. The signals reveal information about the sample, including external morphology, topography, chemical composition, crystalline structure, and orientation of materials making up the sample.

Figure 8 depicts the SEM photograph of the synthesized $\mathrm{Cu}$ (II) complex. We noted that there is a uniform matrix of the synthesized complex in the pictograph and the image of copper complex shows a flower-like shape with $60 \mathrm{~nm}$ particle size, clearly indicating that the $\mathrm{Cu}(\mathrm{II})$ complex is amorphous in agreement with the powder XRD results. The smaller grain sizes found from XRD and SEM suggest that these complexes are polycrystalline with nanosized grains.

\section{Conclusions}

The azo Schiff base complexes of VO(II), Mn(II), $\mathrm{Co}(\mathrm{II}), \mathrm{Ni}(\mathrm{II}), \mathrm{Cu}(\mathrm{II})$, and $\mathrm{Zn}(\mathrm{II})$ obtained from 4-((4chlorophenyl)diazenyl)-2-(( $p$-tolylimino)methyl)phenol (CDTMP) were synthesized and characterized by spectral and analytical methods. Redox couple of the copper(II) complex was assigned as irreversible from their cyclic voltammetric data. CDTMP exhibits appreciable NLO 


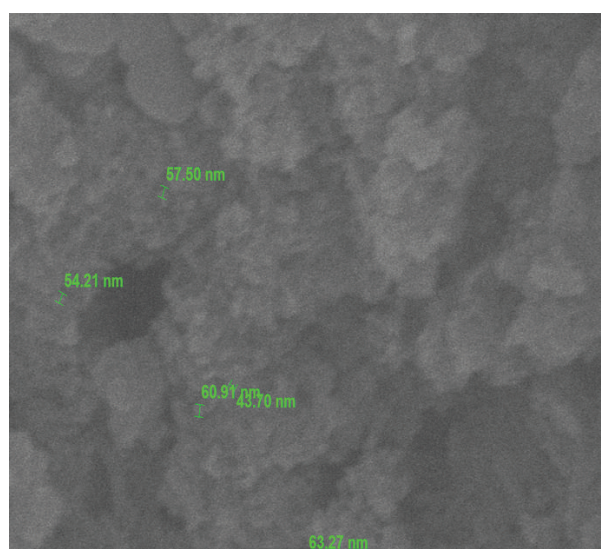

(a)

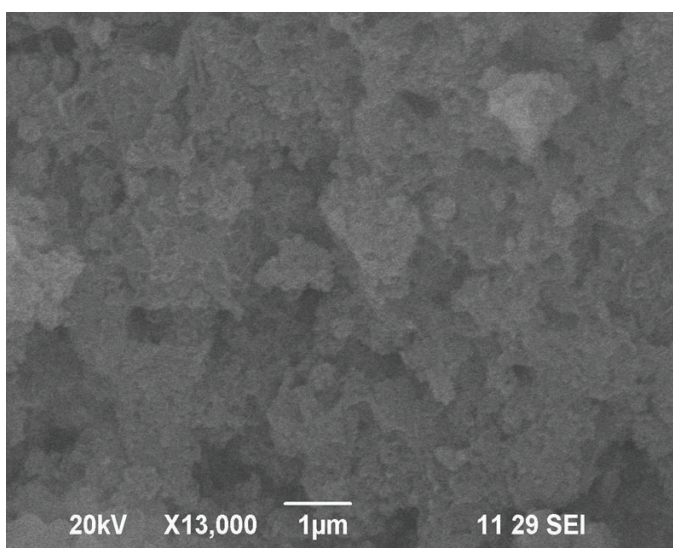

(b)

Figure 8: SEM images of $\left[\mathrm{Cu}(\mathrm{CDTMP})_{2}\right]$.

property in comparison with urea and KDP; hence the compound may be studied for optical sensing material. The ligand and all metal(II) complexes possess appreciable antibacterial and antifungal activities, and the copper(II) complex was found to be more potent than the other complexes due to the nanoparticle size. In general, all the synthesized compound can serve as potential photoactive materials, as indicated from their characteristic fluorescence properties. Based on these results, it could be proposed that these novel azo materials can be better accommodated for technological and pharmaceutical usage.

\section{Acknowledgments}

The authors wish to express their sincere thanks to the Management of Thiagarajar College and The American College, Madurai, India, for constant encouragement and support. The authors would also like to thank SAIF, IIT-Bombay and CDRI, and (SAIF) Lucknow for providing analytical facilities.

\section{References}

[1] P. F. Gordon, The Chemistry and Applications of Dyes, vol. 381, Plenum Press, New York, NY, USA, 1990.

[2] S. A. Hudson and P. M. Maitlis, "Calamitic metallomesogens: metal-containing liquid crystals with rodlike shapes," Chemical Reviews, vol. 93, no. 3, pp. 861-885, 1993.

[3] M. Akkurt, I. Celik, R. Erenler, O. Cakmak, C. C. Ersanli, and O. Buyukgungor, "Trans,trans,trans-2,3,5,8-Tetrabromo1,4-dihydroxy-1,2,3,4-tetrahydronaphthalene," Acta Crystallographica, vol. E60, pp. o2096-o2098, 2004.

[4] K. Ogawa and J. Harada, "Aggregation controlled proton tautomerization in salicylideneanilines," Journal of Molecular Structure, vol. 647, no. 1-3, pp. 211-216, 2003.

[5] P. Ball and C. H. Nicholls, "Azo-hydrazone tautomerism of hydroxyazo compounds-a review," Dyes and Pigments, vol. 3, no. 1, pp. 5-26, 1982.
[6] A. S. Kabeer, M. A. Baseer, and N. A. Mote, "Synthesis and antimicrobial activity of some Schiff bases from benzothiazoles," Asian Journal of Chemistry, vol. 13, no. 2, pp. 496-500, 2001.

[7] P. A. Vigato and S. Tamburini, "The challenge of cyclic and acyclic schiff bases and related derivatives," Coordination Chemistry Reviews, vol. 248, no. 17-20, pp. 1717-2128, 2004.

[8] I. Sheikhshoaie and W. M. F. Fabian, "Quantum chemical study on the electronic structure and second-order nonlinear optical properties of salen-type Schiff bases," Dyes and Pigments, vol. 70, no. 2, pp. 91-98, 2006.

[9] F. Tisato, F. Refosco, and G. Bandoli, "Structural survey of technetium complexes," Coordination Chemistry Reviews, vol. 135-136, pp. 325-397, 1994.

[10] H. Reyes, C. Garcia, N. Farfan et al., "Syntheses, crystal structures, and quadratic nonlinear optical properties in four "push-pull" diorganotin derivatives," Journal of Organometallic Chemistry, vol. 689, no. 14, pp. 2303-2310, 2004.

[11] H. M. A. Salman, A. A. Mohamed, S. A. Ibrahim, and A. A. Ahmed, "Co(II), $\mathrm{Ni}(\mathrm{II}), \mathrm{Cu}(\mathrm{II})$, and $\mathrm{Cd}(\mathrm{II})$ complexes of some new arylazopyrazolopyrimidine derivatives," Synthesis and Reactivity in Inorganic and Metal-Organic Chemistry, vol. 33, no. 8, pp. 1351-1366, 2003.

[12] I. Sheikhshoaie, M. Hossein, Mashhadizadeh, and S. Saeid$\mathrm{Nia}$, "Synthesis, characterization and theoretical study of the structure and second-order nonlinear optical properties of two new monoazo Schiff-base compounds," Journal of Coordination Chemistry, vol. 57, no. 5, pp. 417-423, 2004.

[13] B. S. Furniss, A. J. Hannaferd, and V. Rogers, Vogel's Textbook of Practical Organic Chemistry, vol. 716, Longman, New York, NY, USA, 4th edition, 1981.

[14] K. Nejati and Z. Rezvani, "Syntheses, characterization and mesomorphic properties of new bis(alkoxyphenylazo)substituted $N, N^{\prime}$ salicylidene diiminato $\mathrm{Ni}(\mathrm{II}), \mathrm{Cu}(\mathrm{II})$ and VO(IV) complexes," The New Journal of Chemistry, vol. 27, no. 11, pp. 1665-1669, 2003.

[15] G. G. Mohamed, "Structural chemistry of some new azo complexes," Spectrochimica Acta A, vol. 57, no. 3, pp. 411-417, 2001.

[16] E. Erdem, E. Y. Sari, R. Kilincarslan, and N. Kabay, "Synthesis and characterization of azo-linked Schiff bases and their 
nickel(II), copper(II), and zinc(II) complexes," Transition Metal Chemistry, vol. 34, no. 2, pp. 167-174, 2009.

[17] G. G. Mohamed and S. M. Khalil, "Metal complexes of omeprazole. Preparation, spectroscopic and thermal characterization and biological activity," Journal of Coordination Chemistry, vol. 62, no. 4, pp. 645-654, 2009.

[18] R. C. Maurya and S. Rajput, "Oxovanadium(IV) complexes of bioinorganic and medicinal relevance: synthesis, characterization and 3D molecular modeling and analysis of some oxovanadium(IV) complexes involving the $\mathrm{O}, \mathrm{N}$-donor environment of pyrazolone-based sulfa drug Schiff bases," Journal of Molecular Structure, vol. 794, no. 1-3, pp. 24-34, 2006.

[19] N. Mondal, D. K. Dey, S. Mitra, and K. M. A. Malik, "Synthesis and structural characterization of mixed ligand $\eta 1-2$ hydroxyacetophenone complexes of cobalt(III)," Polyhedron, vol. 19, no. 28, pp. 2707-2711, 2000.

[20] M. M. Omar and G. G. Mohamed, "Potentiometric, spectroscopic and thermal studies on the metal chelates of 1-(2thiazolylazo)-2-naphthalenol," Spectrochimica Acta A, vol. 61, no. 5, pp. 929-936, 2005.

[21] K. Gudasi, S. A. Patil, R. Vadavi, V. Rashmi, R. Shenoy, and M. S. Patil, "Synthesis and spectral studies of $\mathrm{Cu}(\mathrm{II})$, $\mathrm{Ni}(\mathrm{II}), \mathrm{Co}(\mathrm{II}), \mathrm{Mn}(\mathrm{II}), \mathrm{Zn}(\mathrm{II})$ and $\mathrm{Cd}(\mathrm{II})$ complexes of a new macroacyclic ligand N,N'-bis(2-benzothiazolyl)-2,6pyridinedicarboxamide," Journal of the Serbian Chemical Society, vol. 71, no. 5, pp. 529-542, 2006.

[22] A. D. Garnovskii, I. S. Vasilchenko, D. A. Garnovskii, and B. I. Kharisov, "Molecular design of mononuclear complexes of acyclic Schiff-base ligands," Journal of Coordination Chemistry, vol. 62 , no. 2, pp. 151-204, 2009.

[23] P. Tharmaraj, D. Kodimunthiri, C. D. Sheela, and P. Prakash, "Bis-(3,5-dimethyl-pyrazolyl-1-methyl)-(3-phosphanylpropyl)-amine complexes of copper(II), nickel(II), and cobalt(II)," Journal of Coordination Chemistry, vol. 62, no. 8, pp. 1347-1355, 2009.

[24] R. N. Patel, A. Singh, K. K. Shukla, D. K. Patel, and V. P. Sondhiya, "Structural, spectroscopic, and biological studies of N,O donor Schiff base copper(II) complexes," Journal of Coordination Chemistry, vol. 64, no. 5, pp. 902-919, 2011.

[25] W. G. Hanna and M. M. Moawad, "Synthesis, characterization and antimicrobial activity of cobalt(II), nickel(II)and copper(II) complexes with new asymmetrical Schiff base ligands derived from 7-formyanil-substituted diamine-sulphoxine and acetylacetone," Transition Metal Chemistry, vol. 26, no. 6, pp. 644-651, 2001.

[26] C. Gao, X. Ma, J. Tian, D. Li, and S. Yan, "Synthesis, structure, and DNA binding of three reduced amino-acid Schiff-base zinc(II), nickel(II), and cadmium(II) complexes," Journal of Coordination Chemistry, vol. 63, no. 1, pp. 115-123, 2010.

[27] A. D. Kulkarni, S. A. Patil, and P. S. Badami, "Electrochemical properties of some transition metal complexes: synthesis, characterization and In-vitro antimicrobial studies of $\mathrm{Co}(\mathrm{II}), \mathrm{Ni}(\mathrm{II})$, $\mathrm{Cu}(\mathrm{II}), \mathrm{Mn}(\mathrm{II})$ and $\mathrm{Fe}(\mathrm{III})$ complexes," International Journal of Electrochemical Science, vol. 4, no. 5, pp. 717-729, 2009.

[28] E. Konig, "The nephelauxetic effect," in Structure and Bonding, Springer, Berlin, Germany, 1971.

[29] R. N. Patel, N. Singh, D. K. Patel, and V. L. N. Gundla, "Synthesis, characterization and superoxide dismutase studies of square pyramidal copper(II) complexes with bi and tridentate polyamine ligands," Indian Journal of Chemistry A, vol. 46, no. 3, pp. 422-427, 2007.
[30] A. J. Bard and L. R. Faulkner, Electrochemical Methods, Fundamentals and Applications, Wiley, New York, NY, USA, 2nd edition, 2001.

[31] M. Caramen and M. Sharaby, "Preparation, characterization and biological activity of $\mathrm{Fe}(\mathrm{III}), \mathrm{Fe}(\mathrm{II}), \mathrm{Co}(\mathrm{II}), \mathrm{Ni}(\mathrm{II})$, $\mathrm{Cu}(\mathrm{II}), \mathrm{Zn}(\mathrm{II}), \mathrm{Cd}(\mathrm{II})$ and $\mathrm{UO}_{2}(\mathrm{II})$ complexes of new cyclodiphosph(V)azane of sulfaguanidine," Spectrochimica Acta, vol. 62, no. 1-3, pp. 326-334, 2005.

[32] A. Garcia-Raso, J. J. Fiol, B. Adrover et al., "Reactivity of copper(II) peptide complexes with bioligands (benzimidazole and creatinine)," Polyhedron, vol. 22, no. 25-26, pp. 3255-3264, 2003.

[33] G. Matsubayashi, K. Akiba, and T. Tanaka, "Research Article Spectroscopic and electrical properties of $\mathrm{VO}(\mathrm{dmit}) 2$ and $\mathrm{V}(\mathrm{dmit}) 3$ anion complexes and $\mathrm{x}$-ray crystal structure of [NMP]2[V(dmit)3] (dmit = 2-thioxo-1,3-dithiole-4,5dithiolate, NMP = N-methylphenazinium)," Inorganic Chemistry, vol. 27, no. 26, pp. 4744-4749, 1988.

[34] N. Raman, A. Kulandaisamy, A. Shunmugasundaram, and K. Jeyasubramanian, "Synthesis, spectral, redox and antimicrobial activities of Schiff base complexes derived from 1-phenyl-2,3dimethyl-4-aminopyrazol-5-one and acetoacetanilide," Transition Metal Chemistry, vol. 26, no. 1-2, pp. 131-135, 2001.

[35] C. Perez, M. Pauli, and P. Bezerque, "An antibiotic assay by the agar-well diffusion method," Acta Biologiae et Medecine Experimentalis, vol. 15, pp. 113-115, 1990.

[36] Y. Anjaneyula and R. P. Rao, "Preparation, characterization and antimicrobial activity studies on some ternary complexes of $\mathrm{Cu}$ (II) with acetylacetone and various salicylic acids," Synthesis and Reactivity in Inorganic and Metal-Organic Chemistry, vol. 16, no. 2, pp. 257-272, 1986.

[37] B. M. Tweedy, "Plant extracts with metal ions as potential antimicrobial agents," Phytopathology, vol. 55, pp. 910-914, 1964.

[38] C. M. Sharaby, "Synthesis, spectroscopic, thermal and antimicrobial studies of some novel metal complexes of Schiff base derived from $\left[N^{1}\right.$-(4-methoxy-1,2,5-thiadiazol3-yl)sulfanilamide] and 2-thiophene carboxaldehyde," Spectrochimica Acta, vol. 66, no. 4-5, pp. 1271-1278, 2007.

[39] D. Das, B. G. Chand, K. K. Sarker, J. Dinda, and C. Sinha, "Zn(II)-azide complexes of diimine and azoimine functions: synthesis, spectra and X-ray structures," Polyhedron, vol. 25, no. 11, pp. 2333-2340, 2006.

[40] M. R. Provenzano, V. D’Orazio, M. Jerzykiewicz, and N. Senesi, "Fluorescence behaviour of $\mathrm{Zn}$ and $\mathrm{Ni}$ complexes of humic acids from different sources," Chemosphere, vol. 55, no. 6, pp. 885-892, 2004.

[41] X. H. Bu, H. Liu, M. Du, K. M. C. Wong, and V. W. Yam, "Coordinative versatility of 2,3-bis(2-pyridyl)-5,8dimethoxyquinoxaline (L) to different metal ions: syntheses, crystal structures and properties of $[\mathrm{Cu}(\mathrm{I}) \mathrm{L}]_{2}^{2+}$ and $[\mathrm{ML}]^{2+}(\mathrm{M}$ $=\mathrm{Cu}(\mathrm{II}), \mathrm{Ni}(\mathrm{II}), \mathrm{Zn}(\mathrm{II})$ and $\mathrm{Co}(\mathrm{II}))$," Inorganica Chimica Acta, vol. 333, no. 1, pp. 32-40, 2002.

[42] B. A. Yamgar, V. A. Sawant, S. K. Sawant, and S. S. Chavan, "Copper(II) complexes of thiazolylazo dye with triphenylphosphine and $\mathrm{N}_{3}^{-}$or $\mathrm{NCS}^{-}$as coligands: synthesis, spectral characterization, electrochemistry and luminescence properties," Journal of Coordination Chemistry, vol. 62, no. 14, pp. 2367-2374, 2009. 
[43] H. Unver, A. Karakas, and A. Elmali, "Nonlinear optical properties, spectroscopic studies and structure of 2-hydroxy-3methoxy- $N$-(2-chloro-benzyl)-benzaldehyde-imine," Journal of Molecular Structure, vol. 702, no. 1-3, pp. 49-54, 2004.

[44] S. K. Kurtz and T. T. Perry, "A powder technique for the evaluation of nonlinear optical materials," Journal of Applied Physics, vol. 39, no. 8, pp. 3798-3813, 1968. 

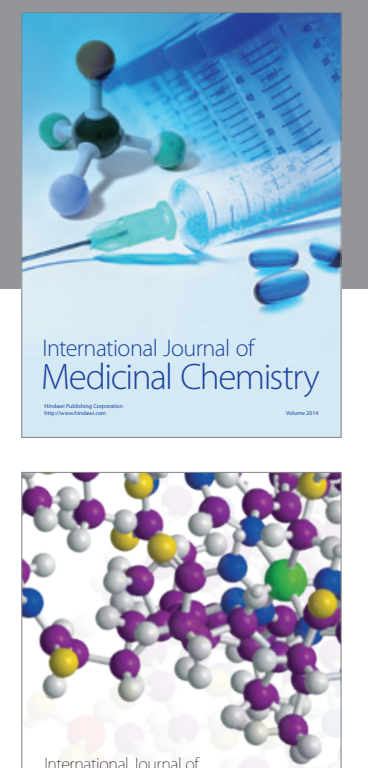

\section{Carbohydrate} Chemistry

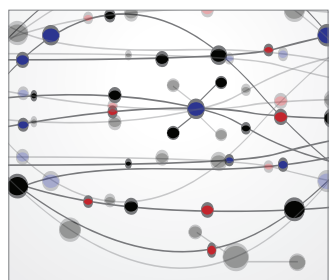

The Scientific World Journal
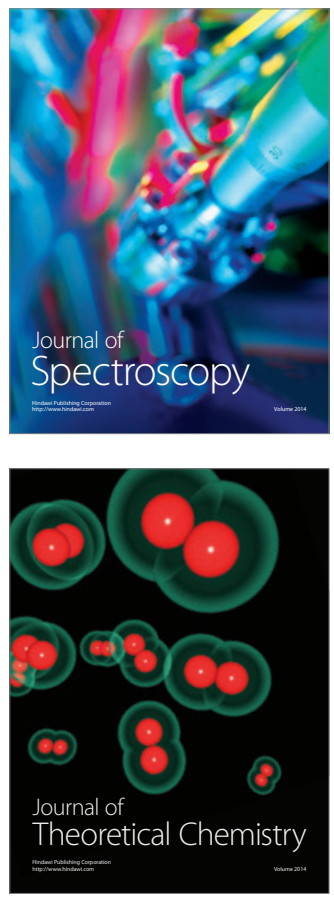
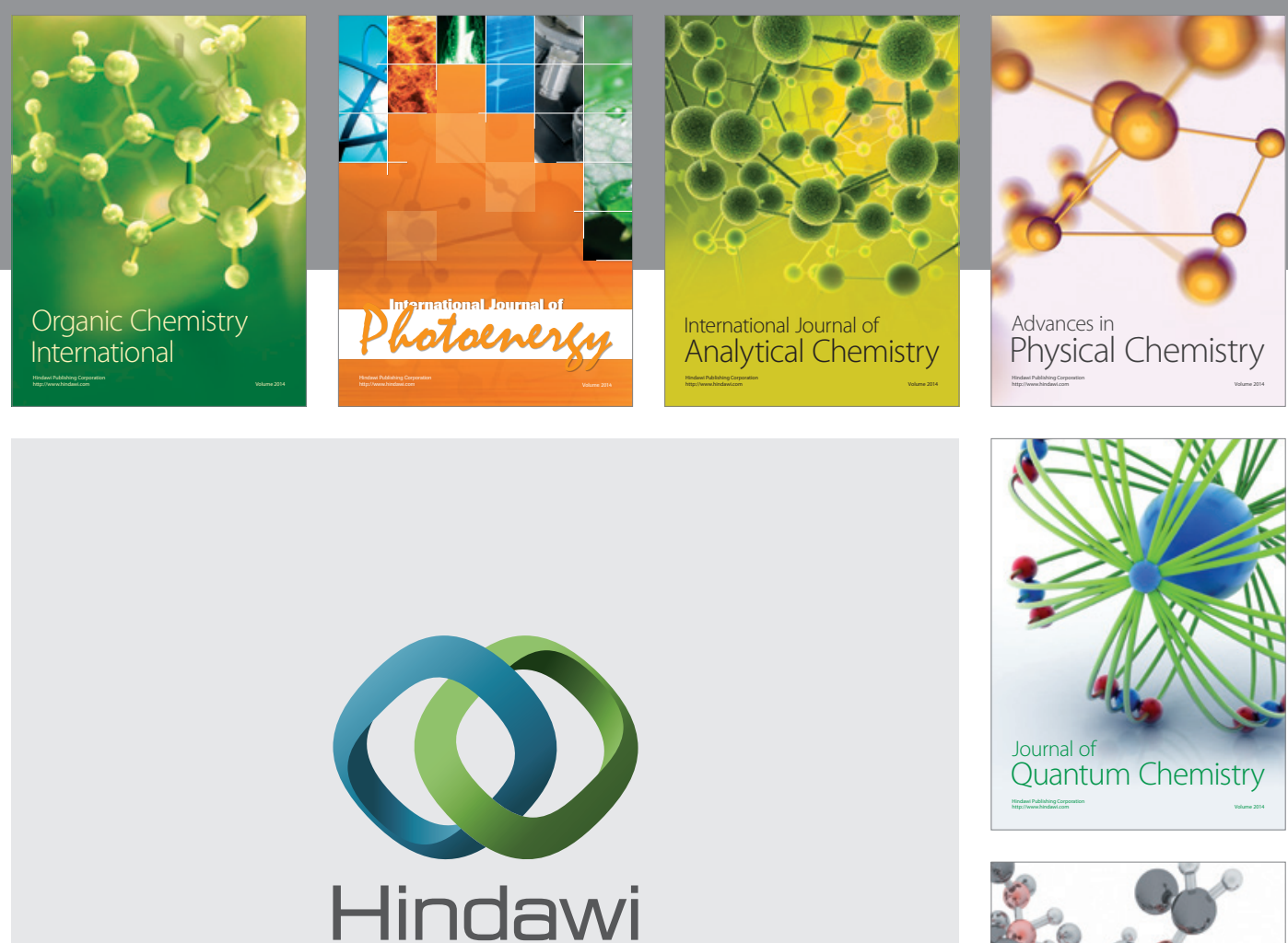

Submit your manuscripts at

http://www.hindawi.com

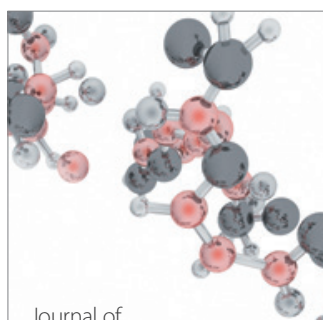

Analytical Methods

in Chemistry

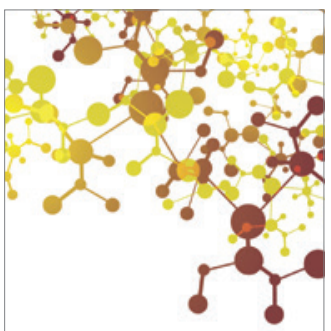

Journal of

Applied Chemistry

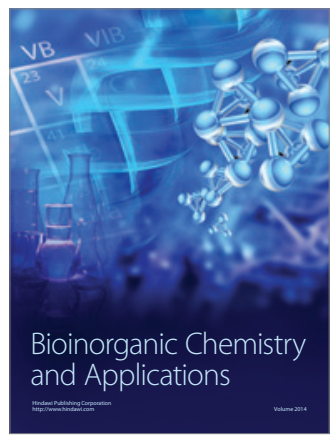

Inorganic Chemistry
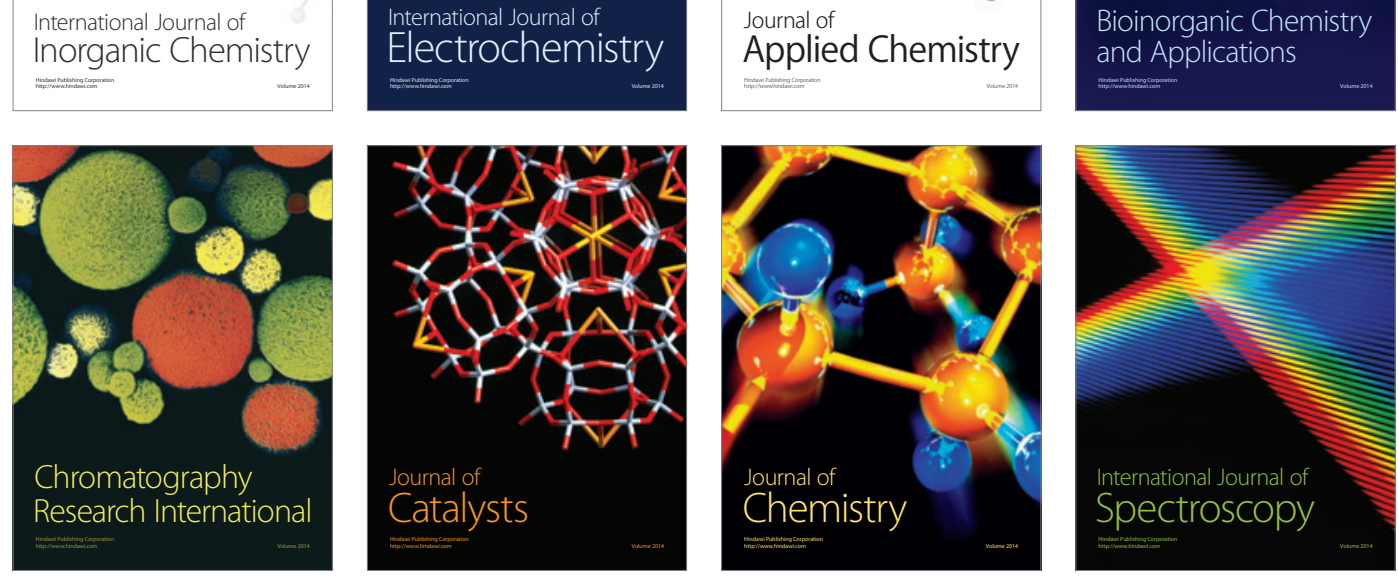